\title{
VITAROVAT
}

\section{Javaslat a hazai láptalajok osztályozásának megújítására}

\author{
MichÉLI Erika, Fuchs Márta, TóTH József Attila, CsORBA Ádám, SzEGI Tamás
}

Szent István Egyetem, Talajtani és Agrokémiai Tanszék, Gödöllő

\section{Bevezetés}

Az úgynevezett ,,szerves talajok” lebomlatlan, vagy csak részlegesen lebomlott növényi maradványok felhalmozódásával képződnek. Különleges anyagi összetételük, képződési körülményeik és földrajzi-, ill. domborzati elterjedésük alapján jelentősen különböznek az ásványi talajoktól.

A tömegükben megörzött hatalmas mennyiségü szerves szénkészlet és környezetük biológiai sokfélesége (biodiverzitása) kapcsán a klímaváltozás által leginkább érintett talajok. Az elmúlt évtized során jelentösen megnövekedett a figyelem e talajok iránt. A tárolt szerves szén mennyiségére, a szerves talajrétegek vastagságára vonatkozó adatigény szintén folyamatosan nő mind a politikai döntéshozók, a klímatudósok, mind pedig a modellezők részéröl a légkörbe kerülő $\mathrm{CO}_{2}$ mennyiség becslése és elörejelzése kapcsán. Mivel e talajok egyedi tulajdonságai sajátos mintavételezési módot és eszközöket igényelnek, valamint vizsgálati módszereik tekintetében is eltérnek az ásványi talajoktól, jelentős hiány tapasztalható a georeferált, szisztematikus monitoring keretében gyüjtött és harmonizált módszerekkel meghatározott adatokban európai, és globális szinten egyaránt.

Objektív, pontos definíciókkal és számszerü határértékekkel meghatározott tulajdonságaik és osztályozásuk, valamint területi kiterjedésük és mélységi megjelenésük harmonizált módszerekkel történő meghatározása a nemzetközi elvárások és adatigények mellett hazai érdekünk is.

Mint más országokban, Magyarországon is számos tudományterület foglakozik a szerves talajokkal, melyek jelentős szemléleti és szóhasználati különbségeket mutatnak.

Jelen dolgozatunk célja a hazai talajtan szerves talajokra vonatkozó osztályozási-, és felvételezési munkálatainak rövid áttekintése, valamint azok eredményinek, és a nemzetközi standardok figyelembevételével a szerves talajok osztályozására vonatkozó javaslatunk bemutatása. A dolgozat része a hazai osztályozás megújítását bemutató cikksorozatnak.

Postai cím: Fuchs MáRTA, Szent István Egyetem, Mezőgazdaság és Környezettudományi Kar, Környezettudományi Intézet, Talajtani és Agrokémiai Tanszék

2100 Gödöllő, Páter K. u. 1.

E-mail: fuchs.marta@gmail.com 


\section{Irodalmi áttekintés}

\section{A szerves talajok kiterjedése}

A szerves talajok bolygónknak mintegy 3\%-át borítják, legnagyobb összefüggő kiterjedésben a hüvös sarkköri területeken (TARNOCAI et al., 2009; JONES et al., 2005, 2010), ahol a holt biomassza felhalmozódása és így a képződés legfontosabb tényezője az alacsony hömérséklet. A talajokban tárolt globális szerves szén becsült mennyisége tág határok között mozog, 1500-3000 Pg között szerepel az irodalomban. Még nagyobb, 10-50\% közötti a szerves talajokban tárolt részarány becslésének változatossága (TARNOCAI et al., 2009; ESWARAN et al., 1993, 2000; BATJES,1996; LAL, 2004; KÖCHY et al., 2015). Ez a jelentős eltérés a becsléshez alkalmazott adatbázisok, a becslés mélységének, és az alkalmazott térfogattömeg értékek eltéréseinek és bizonytalanságának köszönhető.

A hazai szerves talajokat láptalajokként ismerjük. Képződésük leginkább mélyen fekvő térszínek felszínközeli talajvíz által telített környezetéhez köthető. Hazánkban a csapadékvíz által táplált ún. fellápok kialakulásához nem kedvezőek az éghajlati feltételek, az országban mindössze néhány előfordulásuk található (pl. Nyírjes tó, Keleméri-Mohos tavak). A hazai láptalajok kiterjedésére az ország területének 1-1,9\% közötti értékek szerepelnek a különbözö irodalmi és térképi forrásokban (JENEY \& JASSÓ, 1983; STEFANOVITS, 1963; VÁRALLYAY et al., 1979, 1980; DoвOS et al., 2006; PÁSZTOR et al., 2012). További bizonytalanságot okoznak a nevezéktani eltérések, és a láptalajok tulajdonságainak gyors változásai a felvételezéseket követő tőzegkitermelések és a lecsapolások eredményeképp végbement bomlási-, és átalakulási folyamatok miatt (STEFANOVITS, 1972; DöMSÖDI, 1974).

\section{Nevezéktan, osztályozás}

Hazánkban a láptalajoknak nevezett szerves talajképződmények első, tudományos szempontú vizsgálata a tőzeglelőhelyek felderítése érdekében az 1860as években kezdődött. A POKORNY (1863) osztrák botanikus nevéhez füződő korai tőzegkutatások írásos összefoglalója a tőzeglelőhelyek elterjedése, vastagsága és kiterjedése mellett a képződés, fejlődés leírását és a különböző tőzegtípusok jellemzését is tartalmazta. Döntően meghatározta a későbbi tőzegkutatási és felvételezési munkákat is. Ezt követően az 1892-ben megalakult Tözegkutató Bizottság (STAUB, 1894), majd LÁsZLó \& EMSZT (1915) felmérései szolgáltattak új adatokat lápjaink keletkezéséröl és elterjedéséröl - továbbá biztosították az 1946 után, a Magyar Állami Földtani Intézet (MÁFI) által irányított, a kitermelhető tőzegkészletek felmérésére irányuló munkák alapját (DöMSÖDI, 1971).

A hazai lápkutatásokban az 1950-es évektől a tőzegtermelőhelyek kijelölése, és az érvényben levő szabványok szerinti minőségi besorolásuk volt a meghatározó (DöMSÖDI, 1977), az elkészült összefoglalók és kataszterek pedig a már 
rendelkezésre álló adatok (kutatási anyagok, fúrási dokumentációk, térképek) alapján, azok feldolgozásával készültek.

Tőzegterületeink és tőzegvagyonunk átfogó összefoglalóját az ún. „Előzetes Országos Tőzegkataszter” és „Országos Tőzegkataszter” (DöMsöDI, 1970, 1971, 1981) tartalmazza, majd a Természetvédelmi Hivatal megbízásából a lápos réti talajokra is kiterjedően Dömsödi János irányításával elkészült az ún. Lápkataszter (1990-95).

A jelenleg érvényben levő, genetikai szemléletủ hazai osztályozási rendszer megalkotása során STEFANOVITS \& MÁTÉ $(1960,1961)$ tettek javaslatot a láptalajok (fötípus) osztályozására, amely kisebb (főképp nevezéktani) módosításoktól eltekintve napjainkig elfogadott (1. táblázat). Az osztályozás alapjául azon talajtulajdonságokat helyezték, melyek szoros kapcsolatban állnak a talajok fejlödésével, de céljuk volt a szerves talajok agronómiai értékének, valamint az emberi tevékenység hatásának kifejezése is.

\section{1. táblázat}

A láptalajok osztályozása STEFANOVITS \& MÁTÉ $(1960,1961)$ szerint.

\begin{tabular}{|l|l|l|}
\hline Talajtípus & Altípus & Változat \\
\hline Mohaláp & - & - \\
\hline Rétláptalajok & $\begin{array}{l}\text { Tőzegláptalajok }(>50 \mathrm{~cm} \\
\text { lebomlatlan tőzegréteg) } \\
\text { Kotustőzegláptalajok }(>50 \\
\text { cm lebomlatlan tőzegréteg } \\
\text { felett kotu található) } \\
\text { Tőzeges láptalajok }(<50 \mathrm{~cm} \\
\text { lebomlatlan tőzegréteg, } \\
\text { felszínét kotu borítja) } \\
\text { Kotus láptalajok (csak kotu, } \\
\text { tőzegréteg nem található) }\end{array}$ & $\begin{array}{l}\text { Szervesanyag } \\
\text { rétegvastagsága, szerves és } \\
\text { ásványi részek aránya, } \\
\text { talajképző kőzet minősége, } \\
\text { kémhatás és } \\
\text { karbonáttartalom, azok } \\
\text { eloszlása, sófelhalmozódás, } \\
\text { gyökérfejlődést gátló réteg } \\
\text { mélységbeli elhelyezkedése } \\
\text { alapján }\end{array}$ \\
\hline $\begin{array}{l}\text { Lecsapolt és telkesített } \\
\text { síkláptalajok }\end{array}$ & $\begin{array}{l}\text { Lecsapolt tőzegláp } \\
\text { Lecsapolt tőzeges láp } \\
\text { Lecsapolt kotus láptalajok változatainak } \\
\text { megfelelően }\end{array}$ \\
& $\begin{array}{l}\text { Telkesített rétláp (letermelt } \\
\text { vagy felégetett tőzegréteg } \\
\text { esetén) }\end{array}$ & \\
\hline
\end{tabular}

A genetikai alapokon nyugvó láptalaj osztályozást és nomenklatúrát DöMSÖDI $(1979,1980)$ is támogatta. A „Rétláp” és „Lecsapolt és telkesített rétláp talajok” típusának elkülönítését azonban szükségtelennek tartotta, és a hazai rétlápok fúrásdokumentációval igazolt rendkívül nagymértékü antropogén, valamint természetes degradációja és átalakulása alapján a mohaláptalajok típusa mellett csak a különbözö mértékben lecsapolt, ill. telkesített rétláptalajok elkülönítését tartotta szükségesnek. Ez utóbbiak esetében az osztályozás alacsonyabb szintjén hat altípust (Tőzegláptalaj, Kotustőzegláptalaj, Lápföldes tőzegláptalaj, Tőzeges láptalaj, Lápföldes talaj és Kotus talaj), és számos változati tulajdonságot különít el, azonban 
ezek meghatározása erősen leíró jellegủ, pontos definíciókat és számszerủ határértékeket csak elvétve tartalmaz.

A tőzegesedés jellege szerint meghatározott tőzegtípusok, és azok meghatározásai, az alábbiakban összefoglalva, szintén nagy változatosságot mutatnak.

Nyers vagy $\quad$ (STEFANOVITS, 1999) (nincs definíció)

szalmás tőzeg:

Rostos (világos) Abszolút szárazanyagra számítva szervesanyag tartalmának tőzeg: legalább 50 súlyszázalékát $20 \mathrm{~mm}$-nél hosszabb növényi rostok alkotják (DÖMSÖDI, 1980)

Benne a növényi rostok igen jól kivehetőek (SZABOLCS, 1966)

Szuroktőzeg vagy Benne a növényi maradványok szabad szemmel csak érett (fekete) elvétve ismerhetőek fel, nedvesen kenődő, kiszáradva tőzeg: formatartó vagy rögösen széteső (DÖMSÖDI, 1980)

A tőzegfajták legerőteljesebben átalakult változata, amelyben növényi szövetek már nem ismerhetők fel (JASSÓ, 1987; 1989; STEFANOVITS, 1999)

Benne a szervesanyag teljesen humifikálódott és ezért egynemü fekete, vagy barna kenődő anyagot ad (SZABOLCS, 1966)

Vegyes (sötét) A rostos és az érett tőzeg keveréke (DöMSÖDI, 1980)

tözeg:

Lápföld:

Szárazanyagra számítva 40\%-nál több, de legfeljebb $80 \%$ szervetlen anyagot tartalmazó tőzeges talaj (KABAR \& SZABOLCS, 1961)

$30 \%$ nedvességtartalomra vonatkoztatott, $28 \%$-nál nagyobb hamutartalmú tözeg (DöMSÖDI, 1977b)

A tőzeg humifikálódik és ásványi anyagokkal feldúsul, megkülönböztethetők meszes (csigás), kotus (száraz, laza) és kötött (agyagos) lápföldek is (DöMSÖDI, 1980)

Lebomlott tőzeg: $\quad$ (DöMSÖDI, 1980) 
Kotu:

Szervesanyag tartalma legalább 10\%, színe fekete vagy szürke (STEFANOVITS \& MÁTÉ, 1960)

Kotu az a lápi eredetü, fekete vagy szürkés fekete színü felső talajréteg, amelyben a szervesanyagtartalom szárazanyagra számítva legalább $20 \%$, szervesanyaga a kolloidális szerkezetét elveszítette, szárazon morzsalékos, a vizet csak kis mértékben szívja fel (KABAR És SZABOLCS, 1961)

Fekete, könnyű morzsákból álló talajanyag, kiszáradva könnyen esik áldozatul a deflációnak. A szervesanyag elbomlásának eredménye, amelyen az ásványi részek viszonylagos feldúsulása is értendő. A szerves alkotórész az ásványi résszel szorosabban kapcsolódik, mint a humifikált tőzegben. (JASSÓ, 1987; 1989)

A gyors és tartós kiszáradás hatására a tőzeglebomlás intenzitása gyorsabb, száraz, laza, poros „kotu” felszín keletkezik (DöMSÖDI, 1980)

Ásványi anyagokban gazdagabb, de még 10-20\% szerves anyagot tartalmaz (SZABOLCS, 1966; STEFANOVITS, 1999)

A bemutatott osztályozási egységek sokfélesége nehezíti a hazai láptalajok felvételezését, objektív jellemzését és nemzetközi megfeleltetését (MicHÉLI et al., 2006).

A nemzetközi nevezéktanban is tapasztalhatóak eltérések, azonban a két legjelentősebb nemzetközi rendszer, a WRB (Világ Talaj Referenciabázis, IUSS WORKING GROUP WRB, 2015) és az USA osztályozási rendszere, a Soil Taxonomy (SOIL SURVEY STAFF, 1999) igen hasonló definíciókra épülnek. Mégis jelentös eltérés van a szerves területek kiterjedésének meghatározásában, mivel a Soil Taxonomy a hideg területek talajait (Gelisols) a kulcsban első helyen sorolja ki, és így a hideg, fagyos területek szerves talajai nem a Histosols rendben (Order) sorolnak ki.

A Világ Talaj Referenciabázis definíciója alapján a Histosols referencia csoportba olyan talajok tartoznak, amelyeket olyan (definíció szerint legalább 20\% szerves szén tartalmú) szerves talajanyag alkot, amely

1. a talajfelszínen kezdődik, legalább $10 \mathrm{~cm}$ vastagságú, és alatta

közvetlenül

a) jég, vagy

b) egybefüggő természetes kőzet vagy mesterséges kemény anyag, 
c) olyan törmelékes kőzet tálalható, melynek, réseit, repedéseit szervesanyag tölti ki; vagy

2. a talajfelszíntől számított $40 \mathrm{~cm}$-en belül kezdődik, és a felszíntől számított $100 \mathrm{~cm}$-en belül:

a) legalább $60 \mathrm{~cm}$ összesített vastagsággal rendelkezik, ha térfogatának legalább $75 \%$-a tőzegmoha, vagy

b) legalább $40 \mathrm{~cm}$ összesített vastagsággal rendelkezik, ha más anyagokból áll.

A Histosolok további jellemzése a WRB minősítőkkel elsősorban a szerves talaj alatti réteg anyagára és felszín közelségére, a lebomlottság fokára, a többletnedvesség forrására, a kémhatás és bázistelítettségi viszonyokra és további, hazai körülmények között ritkábban elöforduló tulajdonságokra vonatkoznak.

\section{Felvételezés, mintavételezés problémái}

A felvételezés célja és méretaránya alapján a felvételi pontok elrendezése és sủrüsége változó, azonban általánosságban elmondható, hogy mivel a felszínalatti szerves szintek vastagsága, lebomlottsági foka és térfogattömege igen nagy változatosságot mutat, az ásványi talajoknál nagyobb mértékben szükséges sủríteni a mintavételi pontokat. Az ásványi- és a láptalajok tulajdonságainak lényeges különbségei közül mintavételi szempontból fontos kiemelni még a szerves széntartalmat és annak eloszlását, a talaj-aggregátumok hiányát vagy eltérő megjelenését (AGUS et al., 2011). További nehézséget jelent, hogy a láptalajok víztelítettségtől függően erősen duzzadnak, illetve zsugorodnak, tömegük tízszeresét is képesek vízből megkötni (STEFANOVITS,1999). A láptalajokra jellemző nagy pórustérfogat miatt a mintavétel során a legnagyobb gondot a talajminta bolygatatlan, tömörítés nélküli kiemelése jelenti. A lebomlottság mértékétől függően a láptalajok nagy része szerkezet nélküli, a kotusodás eredményeképpen azonban nő a szerkezetesség mértéke. Az ajánlások szerint, 25\% rosttartalomig lehetséges a lápfúró használata. Ennél rostosabb összetételü láptalajok esetén a mintavétel csak szelvényfeltárás útján végezhető el, mintavevő gyűrủ használatával (http 1). Nagy rosttartalom esetén a minták eredeti állapotának megörzése Saran reagenssel történhet, mely bevonattal konzerválja a térfogatot (BRASHER et al., 1966). Szélsőséges vizes körülmények között a gammasugárzáson alapuló térfogattömeg mérés javasolt (VISCARA ROSSEL et al., 2011), azonban különleges anyag és eszközigényük miatt e módszerek nem terjedtek el a hazai gyakorlatban, és alkalmazásuk elterjedése a jövőben sem várható.

\section{Laboratóriumi mérések problémái}

A térfogattömeg laboratóriumi mérésének lépései megegyeznek az ásványi talajok mérésének szabvány szerinti (MSz-08-0205:1978/8) módszerével, azonban a szárítószekrényben való szárítás extrém esetekben akár 96 óráig is tarthat. A láptalajok térfogattömege a lebomlottság mértékének jó indikátora (BOELTER, 
1969), általában 0,05-0,2 $\mathrm{g} \mathrm{cm}^{-3}$ (CHAMBERS et al., 2011), amely müvelés vagy lecsapolás hatására nőhet, de mindig $1 \mathrm{~g} / \mathrm{cm}^{3}$ alatti marad.

A szervesanyag tartalom meghatározása tőzeg és tőzegkészítmények esetén a jelenleg hatályos hazai szabvány (MSz-08-0012-6:1987) szerint izzítási veszteség, és a Tyurin- módszer (BUZÁs, 1988) alapjaira kidolgozott nedves égetéses hazai szabvány (MSZ-08-0452:1980) alkalmazásával történik. A nedves égetésen alapuló módszer során a talaj szervesanyag tartalmát savas közegben oxidálószer segítségével roncsoljuk, majd a feleslegben maradt roncsolószer titrimetriás mérése alapján határozzuk meg a minták szerves széntartalmát. A hazai laboratóriumi gyakorlatban rutinszerüen alkalmazott módszer hátránya, hogy a roncsolás során a talajban található szerves anyagok nem oxidálódnak el teljes mértékben, így különösen nagy szervesanyag tartalmú talajok esetében nem kapunk használható eredményt - a módszer a nagy szervesanyag tartalommal rendelkezö talajok szervesanyag tartalmát erősen alábecsüli.

\section{Módszerek}

A fenti áttekintés és a szerzők hazai és nemzetközi tapasztalatai, ill. az Agrokémia és Talajtan hasábjaiban „Javaslat talajosztályozási rendszerünk megújitására: alapelvek, módszerek, alapegységek" címmel ismertetett dolgozatunkban (MicHÉLI et al., 2015) megfogalmazott módszerek alapján a következő javaslatot tesszük hazai szerves talajaink osztályozásának, és kapcsolódó felvételezési és vizsgálati módszereinek megújítására.

\section{Eredmények}

\section{Javasolt alapdefiníciók a szerves talajok osztályozására}

A talajtípus elnevezése a hagyományoknak megfelelően:

\section{Láptalajok}

A Láptalajok jelentős eltérése és elkülöníthetősége az ásványi talajoktól indokolja, hogy az osztályozási kulcsban elsö helyen szerepelnek. A Láptalajok további osztályozását az altípus és változati tulajdonságok teszik lehetővé (MICHÉLI et al., 2015).

\section{A láptalajok definíciója az osztályozó kulcsban:}

Olyan, év nagyobb részében víztelített körülmények között képződött talajok, melyekben a korlátozottbomlási folyamatok nagymennyiségủ le nem bomlott, vagy csak részlegesen lebomlott szerves anyag felhalmozódását eredményezik.

\section{Osztályozási követelmények:}

Legalább $40 \mathrm{~cm}$ vastag szerves talajszintjük van, amelynek 
1. felső határa a felszínen vagy a felszíntől számított $40 \mathrm{~cm}$-en belül van (nincs mélyebben eltemetödve), és

2. térfogattömege legfeljebb $1 \mathrm{~g} / \mathrm{cm}^{3}$.

Szerves talajszintek: Lebomlatlan vagy részlegesen lebomlott növényi maradványokat tartalmazó szintek, amelynek (izzítási veszteséggel meghatározott) szerves széntartalma legalább $20 \%$.

Keletkezésük, ill. megjelenésük alapján:

Tőzeg szint: Olyan szerves talajszint, mely az év nagyobb részében vízzel telített. A lebomlottság foka (rostos, vegyes, kotus) altípus tulajdonságként definiált.

Elsősorban a nem Láptalajokra (inkább erdő és szikes talajokra) jellemző további szerves talajszintek: alom szint: Olyan szerves talajszint, mely az év nagyobb részében átszellőzött, és erdős vegetációra jellemző növényi maradványokat tartalmaz; gyep szint: Olyan szerves talajszint, mely az év nagyobb részében átszellőzött, és gyepes vegetációra jellemző növényi maradványokat tartalmaz.

Az irodalomban gyakran kerülnek említésre 20\%-nál kevesebb szerves szénnel rendelkező „kotus” szintek. A szerzők tapasztalata alapján a kotus rétegek legalább $20 \%$ szerves széntartalommal rendelkeznek. Az eltérö, a szerves talajanyag kritériumát nem kielégítő anyagot nem kotu-nak, hanem lápföldnek nevezzük. Ennek minimális szerves szén tartalma 10\%. Mélysége a Láptalajok esetében 40 cm-nél sekélyebb (hiszen a szerves szintnek a felszíntől számított $40 \mathrm{~cm}$-en belül kell kezdődnie).

A Láptalajok altípus tulajdonságai (zárójelben jelezve a WRB megfeleltetést):

\begin{tabular}{|l|l|}
\hline rostos tözeges & $\begin{array}{l}\text { A szerves talajanyag térfogatának több mint 2/3-a felismerhető } \\
\text { növényi részeket tartalmaz (Fibric) }\end{array}$ \\
\hline vegyes tözeges & $\begin{array}{l}\text { A szerves talajanyag térfogatának felismerhetö növényi rész } \\
\text { tartalma 2/3-ad és 1/6-od közötti (Hemic) }\end{array}$ \\
\hline kotus & $\begin{array}{l}\text { A szerves talajanyag térfogatának kevesebb, mint 1/6-od része } \\
\text { tartalmaz felismerhető növényi részeket (Sapric) }\end{array}$ \\
\hline mohatőzeges & $\begin{array}{l}\text { A szerves talajanyagot nedves körülmények hatására le nem } \\
\text { bomlott, vagy részlegesen lebomlott tözegmoha (Sphagnumspp.) } \\
\text { alkotja. }\end{array}$ \\
\hline száraztőzeges & Legalább 10 cm vastag alom vagy gyepszint megjelenése (Folic) \\
\hline lápföldes & $\begin{array}{l}\text { Bomlásban előrehaladott, felismerhető növényi részeket nem } \\
\text { tartalmaz, a szerves széntartalom legalább 10\%, de nem éri el a } \\
\text { szerves szintekét }\end{array}$ \\
\hline lecsapolt & A talajvíz szintje szabályozott (Drainic) \\
\hline sekély & $\begin{array}{l}50 \mathrm{~cm} \text {-nél nem vastagabb szerves talajszint(ek)böl álló réteg } \\
\text { jellemzi }\end{array}$ \\
\hline mély & $50 \mathrm{~cm}$-nél vastagabb szerves talajszint(ek)böl álló réteg jellemzi \\
\hline
\end{tabular}


A Láptalajok változati tulajdonságai (zárójelben jelezve a WRB megfeleltetést):

\begin{tabular}{|c|c|}
\hline erőse & $\begin{array}{l}\text { Karbonátfelhalmozódásos szintje* van, vagy másodlagos } \\
\text { karbonát felhalmozódást mutat, melynek felső határa a felszíntől } \\
\text { számított } 100 \mathrm{~cm} \text {-en belül van (Calcic) }\end{array}$ \\
\hline közep & $\begin{array}{l}\text { A talajanyag } 10 \% \text {-os } \mathrm{HCl} \text {-al történő csepegtetés hatására } \\
\text { pezsgő reakciót mutat, és a talajanyag } \mathrm{CaCO}_{3} \text {-tartalma 5-15\% } \\
\text { közötti. }\end{array}$ \\
\hline gyengén ki & $\begin{array}{l}\text { A talajanyag } 10 \% \text {-os } \mathrm{HCl} \text {-al történő csepegtetés hatására } \\
\text { pezsgö reakciót mutat, és a talajanyag } \mathrm{CaCO}_{3} \text {-tartalma } 5 \% \text {-nál } \\
\text { kevesebb (Calcaric) }\end{array}$ \\
\hline telített & $\begin{array}{l}\mathrm{pH}\left(\mathrm{H}_{2} \mathrm{O}\right) \text { legalább 6,5 (Hypereutric) } \\
\text { (csak Láptalajoknál) (**mélységi megjelenés megadható). }\end{array}$ \\
\hline telítetlen & $\begin{array}{l}\mathrm{pH}\left(\mathrm{H}_{2} \mathrm{O}\right) \text { legalább 5,5 de kisebb 6,5- nél(Eutric) } \\
\text { (csak Láptalajoknál) (**mélységi megjelenés megadható).) }\end{array}$ \\
\hline savanyú & $\begin{array}{l}\mathrm{pH}\left(\mathrm{H}_{2} \mathrm{O}\right)<5,5 \text { (Dystric) } \\
\text { (csak Láptalajoknál) (**mélységi megjelenés megadható). }\end{array}$ \\
\hline szoloncsákos & kos talajszintje* van a felszíntöl számított 100 cm-en \\
\hline nátriumos & $\begin{array}{l}\text { A felszíntől számított } 100 \mathrm{~cm} \text {-en belül rendelkezik egy legalább } \\
15 \mathrm{~cm} \text { vastag réteggel, amelyben az adszorbeált } \mathrm{Na} \text { és } \mathrm{Mg} \\
\text { együttes mennyisége legalább } 15 \% \text { a kicserélödési komplexen } \\
\text { (Sodic). }\end{array}$ \\
\hline hordalékos & $\begin{array}{l}\text { Áthalmozott talajanyag felhalmozódása révén keletkezett } \\
\text { rétegzett talajanyag*jelenik meg egy legalább } 25 \mathrm{~cm} \text { vastagságú } \\
\text { rétegben a felszíntôl számított } 100 \mathrm{~cm} \text {-ben belül (Colluvic) }\end{array}$ \\
\hline \multicolumn{2}{|c|}{$\begin{array}{l}\text { *Pontos definícióval rendelkezö diagnosztikus talajszintek, talajtulajdonságok és } \\
\text { talajanyagok (http2) } \\
\text { **felszíntôl: Altípus vagy változati tulajdonság megjelenése a felszíntől a szelvény } \\
\text { egészében } \\
\text { sekély(en): Altípus vagy változati tulajdonság megjelenése a felszíntől számított } 50 \mathrm{~cm} \text {-en } \\
\text { belül } \\
\text { középmély(en):Altípus vagy változati tulajdonság megjelenése a felszíntől számított } 50-100 \\
\text { cm-es rétegben } \\
\text { mély(ben):Altípus vagy változati tulajdonság megjelenése a felszíntől számított } 100 \mathrm{~cm} \text { alatt }\end{array}$} \\
\hline
\end{tabular}

\section{A típus, altípus- és változati tulajdonságok elnevezések javasolt szabályai}

A típus nevét nagybetűvel írjuk, az altípus tulajdonságokat a típus neve előtt jelenítjük meg és csak a legelsőt írjuk nagybetűvel, a változati tulajdonságokat a típus neve után jelenítjük meg. Az altípus- és változati tulajdonságokat a típushoz felsorolt táblázat szerinti sorrendben alkalmazzuk, és azokat egymástól vesszővel választjuk el. Ha talajt leíró szakember a listában nem szerepelő tulajdonságot észlel, akkor azt a változati tulajdonságok végén említheti. Dokumentált új tapasztalatok alapján a típusoknál szerepelő lista bővíthető. 
A Láptalajok definíciója megfeleltethető a WRB Histosols referencia csoportnak. A javasolt további definíciók lényegesen egyszerübbek, rövidebbek a WRB definícióinál, azonban határértékei azokkal megfeleltethetők.

\section{A Láptalajok felvételezési és vizsgálati módszereihez kapcsolódó javaslatok}

A Láptalajok helyszíni minta vételezése során, a kotus területeken a lápfúró használata ajánlott. A lápfúró palástja által kihasított mintából nagyszámú bolygatatlan minta szelése javasolt a térfogattömeg vizsgálathoz. A rostos-, és vegyes tőzeges területeken ásott szelvényfeltárás, és mintavevő gyürủ használata szükséges, ajánlottan a szokásos, $100 \mathrm{~cm}^{3}$-nél nagyobb átméröjü gyürü használatával, a térfogattömeg megbízhatóbb meghatározása céljából. A szerves szén tartalmának meghatározására a szárazégetésen alapuló izzítási veszteség módszerét javasoljuk. Új eszközök egyre inkább hozzáférhetővé válnak mind a helyszíni felvételezés, mind pedig területi lehatárolás tekintetében (CsORBA et al., 2012), melyek a Láptalajok esetében különösen a szervesanyag tartalom felmérésében, és nyomon követesében ígéretesek.

Példák az osztályozásra

Osztályozási példáink 3 talaját a STEFANOVITS \& MÁTÉ 1960-ban megjelent „Javaslat a hazai láptalajok osztályozására” címmel megjelent dolgozatából választottuk, melyek jellegzetes példái a hazai láptalajoknak.

Az első példa hazánk egyik jellegzetes lápvidékéről, a Kis-Balaton területéről származik.

Vörs - Tözeg-láptalaj (STEFANOVITS \& MÁTÉ, 1960)

\begin{tabular}{|l|l|}
\hline $0-40 \mathrm{~cm}$ & Fekete szuroktőzeg, kevés csigahéjjal. \\
\hline $40-150 \mathrm{~cm}$ & $\begin{array}{l}\text { Barna átmeneti tőzeg, melyben a növényi rostok már jól } \\
\text { kivehetők. Néhány helyen 1 cm vastag vízszintesen futó } \\
\text { nemezszerü rostos tôzegréteg található benne. }\end{array}$ \\
\hline $150-200 \mathrm{~cm}$ & $\begin{array}{l}\text { Sárgás színű, kénhidrogénes szagú, rostos tőzeg, melyben a } \\
\text { nádtorzsák és a gyökérrészek még jól felismerhetők. }\end{array}$ \\
\hline $200-250 \mathrm{~cm}$ & Kékes, glejes iszap. \\
\hline & Az egész szelvény kémhatása gyengén savanyú, pH 5,5-6,0. \\
\hline
\end{tabular}

A „Tőzeg- láptalajok” 1960-as leírása szerint, szelvényében „legalább $50 \mathrm{~cm}$ vastag el nem bomlott tőzeg réteggel rendelkeznek, és a felső szintjükben is felismerhetők még a növényi részek maradványai”. Mivel a felső szurok tőzeg réteg elvileg nem tartalmaz rostokat, így a fenti követelményeknek a vörsi talaj csak részben felel meg.

A vörsi szelvény besorolása a javasolt megújitott osztályozás szerint:

Bár szerves szén adat nem áll rendelkezésre, de a leírás alapján egyértelmű a szerves talajszintek jelenléte a 0-200 cm közötti rétegekben, így a legalább $40 \mathrm{~cm}$ vastag szerves talajszintkritérium teljesülésével a talaj típusa Láptalaj. 
A felszíni, 0-40 cm-es réteg nem tartalmaz látható rostokat, tehát kotus, az alatta található rétegek a leírás szerint rostos tözegesek, továbbá a $200 \mathrm{~cm}$ összesített vastagságú szerves talajszintek jelenlétének köszönhetően a talaj kielégíti a mély altípus tulajdonság követelményeit is; míg a pH alapján a talaj felszíntôl telítetlen változatú. Így besorolása:

Sekélyen kotus, középmélyen és mélyen rostos tözeges, mély Láptalaj, felszíntöl telítetlen

WRB megfeleltetése: EutricRheicKatofibricEpisapricHistosol

Második példánk egy másig jellegzetes lápterületünkről, az Ecsedi lápról származik.

Ecsedi láp - Tözeges láptalaj (STEFANOVITS \& MÁTÉ, 1960)

\begin{tabular}{|l|l|}
\hline $0-20 \mathrm{~cm}$ & Fekete kotu, csigahéjas \\
\hline $20-40 \mathrm{~cm}$ & Barnásfekete tőzeges iszap \\
\hline $40-50 \mathrm{~cm}$ & Kékesfekete, tömött iszapos agyag, erösen gipszes \\
\hline $50-100 \mathrm{~cm}$ & Kékes, tarka, vaseres, rozsdás agyag és iszap \\
\hline
\end{tabular}

A „Tőzeges láptalajok” 1960-as leírása szerint, „a tőzeget koturéteg borítja, a tőzegréteg vastagsága kisebb $50 \mathrm{~cm}$-nél”. A leírás szerint a felső $20 \mathrm{~cm}$-es kotu réteg alatt tőzeges iszap van. Amennyiben az kielégíti a tőzeg ismérveit, úgy megfelel az 1960-as követelmények tőzeges láptalajának, ellenkező esetben nem.

Az Ecsedi láp fenti szelvényének besorolása a javasolt megújitott osztályozás szerint:

Szerves szén adat nem áll rendelkezésre, de saját tapasztalatok alapján feltételezzük, hogy a felső $20 \mathrm{~cm}$ fekete kotus réteg megfelel a kotus altípus tulajdonságokkal rendelkező tözeg szint követelményeinek. Az alatta levő iszap szintek azonban nem. Így a legalább $40 \mathrm{~cm}$ vastag szerves talajszint hiányában az ecsedi láp példaszelvénye nem felel meg a Láptalajok követelményinek.

A leírás alapján a Réti talajokhoz tartozik. A felső kotus réteg jelenlétét a réti talajoknál kotus altípus tulajdonságként jelezzük. A szelvény részletes osztályozását a Réti talajok bemutatásánál, ismételt példaként mutatjuk be, cikksorozatunk elkövetkező hasábjain.

Harmadik példánk egy TIM pont a Bodrogközből, melyet a szerzők is vizsgáltak.

Nagyrozvágy - lápos réti talaj (TIM I4805)(TIM, 1995)

A terület lecsapolt. A helyszín meglátogatásakor tapasztalt ellentmondás alapján (megfigyelt rostos tőzeges felszín, ugyanakkor alacsony szervesanyag tartalom) újra mintáztuk és vizsgáltuk a szelvényt. Az itt bemutatott leírás és a laboratóriumi adatok saját mérések, melyek kiegészülnek a TIM „humusz” adatokkal. 
Helyszíni adatok

\begin{tabular}{|l|l|}
\hline $0-45 \mathrm{~cm}$ & Barnásfekete rostos tőzeg \\
\hline $45-70 \mathrm{~cm}$ & Fekete iszapos agyag, szerkezetnélküli, nem pezseg \\
\hline $70-(90) \mathrm{cm}$ & Kékesszürke iszapos agyag, szerkezetnélküli, nem pezseg \\
\hline
\end{tabular}

Laboratóriumi adatok

\begin{tabular}{|l|c|c|c|c|c|c|}
\hline & $\begin{array}{l}\text { Szerves- } \\
\text { szén \% } \\
(\text { LoI) }\end{array}$ & $\begin{array}{l}\text { Humusz\% } \\
\text { TIM * }\end{array}$ & Agyag \% & $\begin{array}{l}\text { Homok } \\
\%\end{array}$ & $\begin{array}{l}\text { Térfogat- } \\
\text { tömeg } \\
\text { g/m }\end{array}$ & $\mathrm{pH}_{\mathrm{H} 2 \mathrm{O}}$ \\
\hline $0-45 \mathrm{~cm}$ & $35 \%$ & $7,7 \%$ & n.a. & n.a & 0,8 & 6,2 \\
\hline $\begin{array}{l}45-70 \\
\mathrm{~cm}\end{array}$ & & 5,5 & $42 \%$ & $21 \%$ & 1,4 & 5,4 \\
\hline $\begin{array}{l}70-(90) \\
\mathrm{cm}\end{array}$ & & 0,7 & $63 \%$ & $13 \%$ & 1,6 & 5,6 \\
\hline
\end{tabular}

*LoI: MSZ-08-0012-6:1987 alapján, TIM: MSZ-08-0452:1980 alapján

$\mathrm{Az}$ eredeti lápos réti talaj TIM szerinti besorolása valószínűleg a nem egyértelmű morfológiai definíciók és a láptalajok szerves anyagtartalmának meghatározására torz értékeket adó módszer alkalmazása alapján történhetett. Ez rámutat az objektív meghatározások és a megfelelő módszer alkalmazásának jelentőségére.

A nagyrozvágyi talaj az 1960 definíciók és a fenti adatok alapján:

Lecsapolt tözeges láptalaj

A nagyrozvágyi talaj szelvényének besorolása a javasolt megújított osztályozás szerint:

Laboratóriumi méréseink alapján a $0-45 \mathrm{~cm}$ vastagságú felszíni réteg 20\%-ot meghaladó szerves szén tartalma kielégíti a tözeg szint kritériumát, és így a talaj típusa (a legalább $40 \mathrm{~cm}$ vastag szerves talajszint jelenlétének köszönhetően) Láptalaj. A látható, nagy arányú (>2/3) rosttartalom alapján rostos-, a szabályozott talajvízszintnek köszönhetően lecsapolt-,valamint az $50 \mathrm{~cm}$-nél sekélyebb szerves talajszint jelenléte alapján sekély altípus; az alacsony $\left(5,5-6,5\right.$ közötti) $\mathrm{pH}\left(\mathrm{H}_{2} \mathrm{O}\right)$ értékek alapján pedig felszíntöl telítetlen változat megállapítható.

Mindezek alapján besorolása:

Rostostözeges, lecsapolt, sekély Láptalaj, felszíntöl telítetlen.

WRB megfeleltetése: EutricRheicDrainicEpifibricHistosol

\section{Következtetések}

A láptalajok objektív felvételezését, térképezését, változásaik nyomon követését és nemzetközi megfeleltetését szolgáló javaslatokat tettünk a Láptalajok osztályozásának megújítására. Előzetes teszteléseink és szakmai egyeztetések alapján egyértelműbb, ismételhető és a nemzetközi standardokkal összhangban levő 
osztályozás támogatja a hazai talajtani kutatási, gyakorlati és oktatási feladatok megoldását.

\section{Összefoglalás}

A szerves talajok összetétele, képződési körülményei, és földrajzi, ill. domborzati elterjedése jelentősen eltér az ásványi talajokétól. A tömegükben megörzött hatalmas mennyiségü szerves szén és környezetük biológiai sokfélesége (biodiverzitása) kapcsán a klímaváltozás által leginkább érintett talajok, ezért megkülönböztetett figyelem irányul e talajokra. Kiterjedésükre, lebomlottsági fokukra, szerves szénkészletükre igen eltérő irodalmi és térképi adatok állnak rendelkezésre. Ugyanakkor éppen a klímaváltozás vonatkozásában óriási a globális és helyi megbízható adatigény az említett kérdésekben. Hazai láptalajaink osztályozási, felvételezési és mintavételi módszereinek megújítására teszünk javaslatot a nemzetközi standardok figyelembe vételével. A megújított Láptalaj meghatározásban a legfontosabb követelmények a 20\% szerves széntartalomra, a 40 $\mathrm{cm}$ vastagságra és az alacsony térfogattömegre vonatkoznak. Az altípus és változati tulajdonságok a lebomlottság fokát, a mélységi, kémhatás viszonyokat, ill. sók jelenlétét adják meg. A szervesanyag meghatározásra az izzítási veszteség módszerét, a térfogattömeg meghatározás mintavételezésére a rostosság függvényében a lápfúró alkalmazását vagy feltárt szelvényből nagytérfogatú bolygatatlan mintákat javasolunk.

Kulcsszavak: Talajosztályozás, diagnosztikus szemlélet, szerves talajok, lápok talajfelvételezése

\section{Irodalom}

Agus, F.,Hairiah, K., Mulyani A., 2011. Measuring carbon stock in peat soils: practical guidelines. Bogor, Indonesia: World Agroforestry Centre (ICRAF) Southeast Asia Regional Program, Indonesian Centre for Agricultural Land Resources Research and Development. 60p.

BATJES, N. H., 1996. Total carbon and nitrogen in the soils of the world. European journal of soilscience, 47.2: 151-163.

BoElTER, D.H., 1969. Physical properties of peats as related to degree of decomposition. Soil Science Society of America Proceedings. 33. 606-609.

Brasher, B. R., Franzmeier, D. P., VAlassis, V. T., Davidson, S. E., 1966. Use of Saranres into coat natural soil clods for bulk density and water-retention measurements. Soil Sci. 101:108.

BuZÁs, I.,(szerk.) 1988.Talaj- és Agrokémiai vizsgálati módszerkönyv 2. A talajok fizikai-kémiai és kémiai vizsgálati módszerei. Mg-i Kiadó, Budapest. p.152-15

Chambers, F.M., BeILman, D.W., YU, Z., 2011. Methods for determining peat humification and for quantifying peat bulk density, organic matter and carbon content for palaeostudies of climate and peatland carbondynamics. Mires and Peat, Volume 7 (2010/11), Article 07, 1-10. 
CsORBA, Á., LÁNG, V., FenYvesi, L., Michéli, E., 2012. Reflektancia spektroszkópia alkalmazása talajok szervesszén- és $\mathrm{CaCO}_{3}$-tartalmának becslésében. Agrokémia és Talajtan, 61 (2), 277 - 290 pp.

Dobos, E., Michel, E., Montanarella, L., 2006. The population of a 500-m resolution soil organic matter spatial information system for Hungary. Developments in Soil Science, 31 487-628.

DöMSÖDI, J., 1970. Elözetes Országos Tőzegkataszter. I. Szöveges rész. II. Táblázatok. III. Térképek (Müszaki, gazdasági, tervezési segédlet). Helyi ipari Kutató Intézet, Budapest.

DöMSÖDI, J., 1971. Magyarország tőzeg- és lápföldkészletének előzetes felmérése. Agrokémia és Talajtan 20. (3) pp. 411-418.

DöMSÖDI, J., 1974. A lecsapolások hatása a Hanság medence tőzeg- és lápföldkészletére. Agrokémia és Talajtan, 23. (3-4), 445 - 460 pp.

DÖMSÖDI J.,1977. Lápi eredetű szervesanyag-tartalékaink mezőgazdasági hasznosítása. Mezőgazdasági Kiadó, Budapest, 123 p.

DÖMSÖDI J.,1977b. A hazai tőzegnyersanyagok fizikai és kémiai (technológiai) tulajdonságai. Agrokémia és Talajtan 26. (1-2) pp. 163-170.

DöMSÖDI J.,1979. A lápképződés, lápmegsemmisülés és a talajképződés kölcsönhatásai. Agrokémia és Talajtan 28. (3-4) pp. 511-526.

DöMSÖDI J.,1980. A hazai tőzeglápok (tőzegek) osztályozása. Földrajzi Értesítő 29. (4) pp. 485-495.

DöMSÖDI, J., 1981. Országos Tőzegkataszter. Építésügyi Minőségellenőrző Intézet Földmérő és Talajvizsgáló Vállalat, Budapest.

Eswaran, H., VAn Den Berg, E., ReICH, P.,1993. Organic carbon in soils of the world. Soil science society of America journal, 57. (1) 192-194.

Eswaran, H., Reich, F.P., Kimble, J.M., Beinroth, F.H., Padamnabhan, E., MonChAROEN, P., 2000. Global carbonstocks. In: Lal, R.,Kimble, J.M., Eswaran, H., Stewart, B.A. (Eds.), Global climate change and pedogenic carbonates. CRC/Lewis, Boca Raton, FL

IUSS WORKING GROUP WRB, 2015. World Reference Base for Soil Resources 2014, update 2015 International soil classification system for naming soils and creating legends for soil maps. World Soil Resources Reports No. 106. FAO, Rome.

JASSÓ F. (szerk.), 1987. Útmutató a nagyméretarányú országos talajtérképezés végrehajtásához. Melioráció - öntözés és tápanyaggazdálkodás.'87 melléklet. Agroinform. Budapest.

JASSÓ F. (szerk.), 1989. Útmutató a nagyméretarányú országos talajtérképezés végrehajtásához. Melioráció - öntözés és talajvédelem.'88 melléklet. Agroinform. Budapest.

JENEY, I., JASSÓ, F., 1983. Magyarország genetikus talajtérképe (méretarány: 1:200.000). Kartográfiai Vállalat, Budapest.

Jones, A., Montanarella, L., Jones, R. (EDS.), 2005. Soil Atlas of Europe. European Soil Bureau Network European Commission, 2005, 128 pp. 
Jones, A.,Stolbovoy, C., Tarnocai, G., Broll, O., SpaArgaren, O., MONTANARELLA, L. (EDS.), 2010.Soilatlas of the Northern Circum polar Region. European Commission, Publ. Office of the European Union, Luxembourg, $144 \mathrm{p}$.

KabaR, Z. \& Szabolcs, I., 1961. Hozzászólás Stefanovits Pál és Máté Ferenc: Javaslat a hazai láptalajok osztályozásához címü dolgozatához. Agrokémia és Talajtan, 10. (2), 293-296.

KÖCHY, M., HIEDERER, R.,FrEIBAUER, A., 2015. Global distribution of soil organic carbon - Part 1: Masses and frequency distributions of SOC stocks fort het ropics, permafrost regions, wetlands, and the world. Soil, 1, 351-365.

LAL, R., 2004. Soil carbon sequestration to mitigate climate change. Geoderma, 123. (1) $1-22$.

LÁsZLÓ, G. \& EMSZT, K.,1915. A tőzeglápok és előfordulásuk Magyarországon. Földtani Intézet kiadványa, Budapest.

Michéli, E., Fuchs, M., HegYmegi, P., Stefanovits, P., 2006. Classification of the major soils of Hungary and their correlation with the World Reference Base for Soil Resources (WRB). Agrokémia és Talajtan. 55 (1) 19-28.

Michéli, E., Fuchs, M., LÁng, V., SZEGi, T., Dobos, E., SZABÓnÉ Kele, G., 2015. Javaslat talajosztályozási rendszerünk megújítására: alapelvek, módszerek, alapegységek. Agrokémia és Talajtan 64. (1) 285-297.

MSZ-08-0205:1978. A talaj fizikai és vízgazdálkodási tulajdonságainak vizsgálata. Magyar Szabványügyi Testület, 39. p.

MSZ-08-0012-6:1987. Tőzeg és tőzegkészítmények fizikai, biológiai és kémiai vizsgálata. A szervesanyagtartalom és a szerves széntartalom meghatározása. Magyar Szabványügyi Testület, 4. p.

MSZ-08-0452:1980. A talaj szerves széntartalmának mennyiségi meghatározása Contiflo müszersoron. Magyar Szabványügyi Testület, 7. p.

PÁSZTOR L., SZABÓ J., BAKACSI Zs., LABORCZI, A., 2012. Elaboration and applications of Spatial Soil Information Systems and Digital Soil Mapping at RISSAC HAS. Geocarto International. 27. (3), 15. p.

POKORNY, L.,1863. Magyarország tőzeg képletei. Matematikai es Természettudományi Közlemények II. Pest. 78-144 p.

SOIL SURVEY STAFF, 1999. Soil taxonomy: A basic system of soil classification for making and interpreting soil surveys. 2nd edition. Natural Resources Conservation Service. U.S. Department of Agriculture Handbook 436.

StAUB, M., 1894. A tőzeg elterjedése Magyarországon. Földtani Közlöny (24), 275369.

StefANOvits, P. \& MátÉ, F.,1960. Javaslat a hazai láptalajok osztályozására. Agrokémia és Talajtan. 9. (2) 277-283.

Stefanovits, P. \& MÁtÉ, F.,1961. Válasz Kabar Zoltán és Szabolcs István hozzászólására. Agrokémia és Talajtan. 10. (2) 296-298.

StefANOVITS, P., 1963. Magyarország talajai 2. Bővített, átdolgozott kiadás. Akadémiai Kiadó. Budapest.

StefANOVITS, P., 1972. Talajtan. Mezőgazda Kiadó. Budapest. 
Stefanovits, P., 1999. A talajok osztályozása. In: Stefanovits, P., FileP, Gy. \& FÜLEKY, GY. Talajtan. 239-320. Mezőgazda Kiadó. Budapest.

SZABOLCS, I. (Ed.) 1966. A genetikus üzemi talajtérképezés módszerkönyve. OMMI Genetikus Talajtérképek. Ser. 1. No. 9. OMMI. Budapest.

Tarnocai, C., Canadell, J. G.,Schuur, E. A. G.,Kuhry, P., Mazhitova, G.,ZiMOV, S., 2009. Soil organic carbon pools in the northern circumpolar permafrost region. Global biogeochemical cycles, 23, GB2023

TIM (TALAJVÉDELMI INFORMÁCiós és MONITORING RENDSZER). 1995. Módszertan. Földművelésügyi Minisztérium Növényvédelmi és Agrárkörnyezetgazdálkodási Főosztály, Budapest.

VÁRALlyay, G., SZÜCS L, MURÁNYI A, RAJKAi K, ZILAHY P., 1979. Magyarország termőhelyi adottságait meghatározó talajtani tényezők 1:100 000 méretarányú térképe I. Agrokémia és Talajtan, 28. (3-4), pp.363-384.

VÁRALLYAY, G., SZÜCS L, MURÁNYI A, RAJKAI K, ZILAHY P., 1980. Magyarország termőhelyi adottságait meghatározó talajtani tényezök 1:100 000 méretarányú térképe II. Agrokémia és Talajtan, 29 (1-2), pp.35-76.

Viscarra Rossel, R.A., AdAMChUK, V.I., SUDDUTH, K.A., McKenZIE, N.J., LOBSEY, C., 2011. Proximal soil sensing: an effective approach for soil measurements in space and time. Adv. Agron., 113, 243-291.

\section{Online irodalom}

http 1:https://en.eijkelkamp.com/products/augering-soil-sampling-equipment/peatsampler.html (2017.02.15)

http2: http://cms.talaj.hu/wp-content/uploads/2015/02/DiagKat_2015.pdf

(2017.02.15) 


\title{
Recommendation for updating the classification of organic soils in Hungary
}

\author{
Erika MichÉLI, Márta Fuchs, József Attila TóTH, Ádám CsORBA, Tamás SzEGI \\ Department of Soil Science and Agricultural Chemistry, \\ Szent István University, Gödöllö, Hungary
}

\begin{abstract}
Summary
The composition, genesis and geographical distribution of organic soils are significantly different from mineral soils. Because of the huge amount of organic carbon preserved in the mass of these soils and biodiversity of their environment, they are the most vulnerable soils to climate change, calling special attention to them. There are wide range of values for their spatial extent and organic carbon stock in the literature, but at the same time there is a great need for reliable global and local data especially in regard of climate change. In this paper recommendation is made for updating the classification of organic soils in Hungary with consideration of international standards. In the modified definition of the "Peat soils" the major classification requirements are the minimum $20 \%$ organic carbon content, the $40 \mathrm{~cm}$ depth and the low bulk density. On the subtype and variety level the degree of decomposition, the depth, $\mathrm{pH}$ and saturation conditions and the presence of salts are defined. For the determination of organic carbon content, the loss on ignition method is recommended. The size, the amount, and the technique of sampling of the undisturbed samples for the bulk density measurements should be determined according to the fiber content, and the variability.
\end{abstract}

Key words: soil classification, diagnostic approach, organic soils, survey of organic soils

Table 1. Classification of organic soils according to STEFANOVITS and MÁté (1960. 1961). 